\title{
GC/MS Analysis and Antibacterial Activity of the Essential Oil of Moroccan Tetraclinis articulata (Vahl) Masters
}

\author{
Halima Rabib ${ }^{1, *}$, Sophia Zougagh ${ }^{2}$, Mohamed Hssain ${ }^{2}$, Wadi Badri ${ }^{2}$ and Tayeb Koussa ${ }^{1}$ \\ ${ }^{1}$ laboratory of Plant Biotechnology, Ecology and Ecosystem Valorization, Faculty of Sciences Bouchaib \\ Doukali, Department of Biology, Route Ben Maachou, 24000, El Jadida, Morocco \\ ${ }^{2}$ Ecology Laboratory and Environment, Faculty of Sciences Ben M'sik, Department of Biology. \\ Av Driss El Harti, Sidi Othman, Casablanca, P.B. 7955, Morocco.
}

\begin{abstract}
The quality and the variability of the chemical composition and antimicrobial properties of essentials oils isolated from Tetraclinis articulata (Vahl) leaves, which were studied from two different regions that are ecologically various. The average yield of essential oil is $0,56 \%$ for the Ras Elma Tazekka region (mountain) and $0,36 \%$ for the Debdou region (plain). An analysis made by GC and GC/ MS identified 22 components in Tetraclinis articulata leaves essential oil in the mountain area and 29 components in the plain area. These major components represent the variability of quantity. The percentages following respectively by the two areas are: Bornyl acetate $(34,84 \% ; 32,55 \%), \alpha$-Pinene $(11,41 \% ; 18,83 \%)$, Camphor $(11,24 \% ; 11,31 \%)$, Limonene $(11,94$ $\% ; 8 \%)$ and Borneol $(8,35 \% ; 7,79 \%)$. The antimicrobial activity of T. articulata essential oil was tested against clinical isolates of Staphylococcus aureus, Pseudomonas aeruginosa and Escherichia coli which has been inhibited from the $50 \mu \mathrm{g} / \mathrm{mL}$ concentration for the Debdou region (Plain) and $25 \mu \mathrm{g} / \mathrm{mL}$ for that of the Ras Elma Tazekka region (Mountain).
\end{abstract}

Keywords: Tetraclinis articulata (Vahl); leaves; essential oil; chemical composition; antimicrobial activity.

\section{Introduction}

The Barbary thuja, Tetraclinis articulata (Vahl) Masters, a member of the Cupressaceae family, is an endemic species of North Africa (Morocco, Algeria, and Tunisia). Outside this zone, we find small localities in southeastern Spain (Cartagena province) as well as Malta Island ${ }^{1}$. The surface area of Tetraclinis woodlands is estimated at 565798 ha, which represents approximately $10 \%$ of the total forest cover in Morocco and the majority of the Moroccan Tetraclinis areas are more likely to be in the temperate and warm semi-arid bioclimatic zone. Tetraclinis articulata is a rustic thermophilous species that thrive in harsh environmental conditions, within the $250-900 \mathrm{~mm} /$ year rainfall range ${ }^{2}$

This species also grows in the sub-humid and arid upper domains, indifferently of the nature of the substrate (limestone or siliceous). However, these forests species are leaking poorly drained clay soils ${ }^{3}$. Different parts of $T$. Articulata are used as remedies in folk medicine due to supposed antirheumatic 1, antipyretic and antidiarrhoea properties ${ }^{4}$.
For thousands of years due to an upsurge in antibiotic-resistant infections, the search for new prototype drugs to combat infections is an absolute necessity and in this regard plant, essential oils may offer great potential and hope. These products have frequently been reported to be antimicrobial agents 5,6 .

The essential oils (EOs) from $T$. articulata leaves are rich in compounds such as $\alpha$-Pinene, Camphor, Borneol and Bornyl acetate ${ }^{7,8}$ used in the food and pharmaceutical industry, cosmetics and perfumery. In an ethnopharmacological study conducted in eastern Morocco, Ziyyat et al. ${ }^{9}$ have reported that Thuja of Barbary leaves are used against diabetes and hypertension.

The purpose of this work is to determine the chemical composition as well as the antibacterial activity in the essentials oils extracted from the leaves of $T$. articulata (Vahl) harvested in the two different regions of Morocco. 


\section{Materials and methods}

\section{Plant}

The leaves of $T$. articulata were collected by Pr. M. HSSAIN in April 2016 at two regions: Debdou (plain, Latitude: $34^{\circ} 03$ '15"; Longitude: W 0259' 15"; Altitude: $765 \mathrm{~m}$ ), The climate was semi-humid, and the vegetation floor was Thermo-Mediterranean; and Ras Elma Tazekka (Mountain, Latitude: $34^{\circ} 03^{\prime}$ 03"; Longitude: W 04¹0' 07"; Altitude: 1496 m), The climate was sub-humid and the vegetation floor was Meso-Mediterranean.

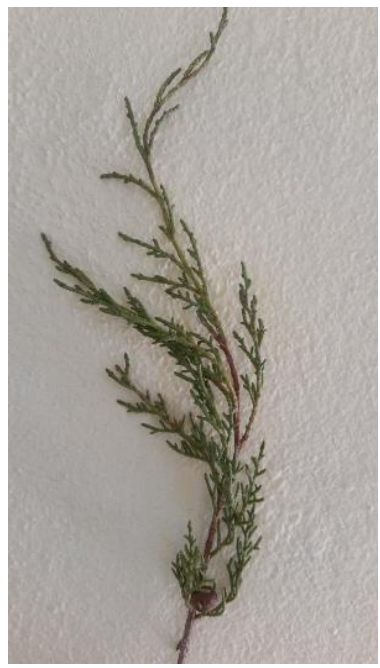

Figure 1. Tetraclinis articulata plant

\section{Extraction methods}

The leaves of T. articulata were shade-dried (09 days) 10 at room temperature minced and immediately hydrodistilled (100g) for 3 hours using a modified Clevenger-type apparatus. For each sample, three experiments were conducted. The oil was extracted from the distillate with hexane and the pure oil kept at $4^{\circ} \mathrm{C}$ in the dark, until the moment of analysis.

\section{Gas chromatography analysis (GC-FID)}

The isolated oil was diluted with hexane, and $1 \mu \mathrm{L}$ was sampled for the gas chromatographic analysis. Trace GC (ULTRA S/N 20062969, Thermo Fischer), gas chromatograph equipped with HP-5MS nonpolar fused silica capillary column $(60 \mathrm{~m} \times 0.32$ $\mathrm{mm}$, film thickness $0.25 \mu \mathrm{m}$ ) was used. Operating conditions: oven temperature program from $50^{\circ} \mathrm{C}$ (2 $\mathrm{min}$ ) to $280^{\circ} \mathrm{C}$ at $5^{\circ} \mathrm{C} / \mathrm{min}$ and the final temperature kept for $10 \mathrm{~min}$; «split mode" ratio 1:20; carrier gas Nitrogen $(\mathrm{N})$, flow rate $1 \mathrm{~mL} / \mathrm{min}$; temperature of injector and detector (FID) were fixed at $250^{\circ} \mathrm{C}$ and $280^{\circ} \mathrm{C}$, respectively.

\section{Gas chromatography-mass spectrometry analysis (GC/MS)}

GC/MS analyses were performed on a Thermo Fischer capillary gas chromatograph directly coupled to the mass spectrometer system (model GC ULTRA S/N 20062969; Polaris S/N 210729). HP- 5MS non polar fused silica capillary column $(60 \mathrm{~m} \times 0.32 \mathrm{~mm}$, $0.25 \mu \mathrm{m}$ film thickness) was used under the following conditions: oven temperature program from $50^{\circ} \mathrm{C}(2 \mathrm{~min})$ to $280^{\circ} \mathrm{C}$ at $5^{\circ} \mathrm{C} / \mathrm{min}$ and the final temperature kept for $10 \mathrm{~min}$; injector temperature, $260^{\circ} \mathrm{C}$; carrier gas $\mathrm{He}$, flow rate $1 \mathrm{~mL} / \mathrm{min}$. The volume of the injected specimen was $1 \mu \mathrm{l}$ of diluted oil in hexane; splitless injection technique; ionization energy $70 \mathrm{eV}$, in the electronic ionization (EI) mode; ion source temperature $200^{\circ} \mathrm{C}$; scan a mass range of $\mathrm{m} / \mathrm{z} 40-650$ and interface line temperature $300^{\circ} \mathrm{C}$

The constituents of essential oils were identified in comparison with their spectres of mass with those gathered in a library of (NIST-MS) type and with those reported in the literature ${ }^{11,12}$.

\section{Determination of antibacterial activity}

The antimicrobial activity of the EOs was tested against Gram-negative Escherichia coli ATCC25922 and Pseudomonas aeurginosa ATCC27853; Grampositive Staphylococcus aureus ATCC29213.

The aromatogram was performed on Petri dishes filled with Muller-Hinton agar. Whatman paper discs (6mm) impregnated with $10 \mu \mathrm{L}$ of essential oil are deposited on the surface of the agarose pre-seeded with $100 \mu \mathrm{L}$ suspensions of $10^{8} \mathrm{cfu} / \mathrm{mL}$. The Petri dishes are then closed and left at room temperature for $30 \mathrm{~min}$ so that the essential oil diffuses; then they are incubated at $37^{\circ} \mathrm{C}$ for 24 hours. After incubation, the results are interpreted by measuring the zones of inhibition ${ }^{13}$.

The minimal inhibitory concentration (MIC) values were evaluated according to published procedures 14-17 MICs were determined by the modified micro-dilution method of CLSI (2006) on round-bottomed 96-well micro-plates. The bacterial suspensions at $108 \mathrm{cfu} / \mathrm{mL}$ were diluted 1/1000 with the same culture medium (TS) to have a concentration of $105 \mathrm{cfu} / \mathrm{mL}$.

The first ten columns of the microplate are filled with different concentrations of essential oil. The essential oil was diluted with tween 80 to $1 \%$ in such a way as to have a concentration of $500 \mathrm{mg} / \mathrm{mL}$. Then from this solution, a series of $1 / 2$ dilutions was prepared to obtain a fork of concentration between $500-1 \mathrm{mg} / \mathrm{mL}$. The ten microplate columns are filled with $90 \mu \mathrm{L}$ of bacterial suspension and then $10 \mu \mathrm{L}$ of the corresponding concentration from the lowest to the highest concentration, in a final range of $0.1-50 \mathrm{mg} / \mathrm{mL}$.

The negative control (column No. 11) was chosen to fill the wells with $100 \mu \mathrm{L}$ of sterile broth. For positive control wells (Column No. 12) were filled with $100 \mu \mathrm{L}$ of the standardized microbial suspension at $105 \mathrm{ufc} / \mathrm{mL}$. 
The plates were then incubated at $37^{\circ} \mathrm{C}$ for 24 hours.

Each test is repeated three times to minimize the experimental error.

\section{Results and discussions}

Yield and chemical composition
The average yield of essential oil extracted from the leaves of T. articulata (Vahl), is $(0,36 \%)$ for the Debdou region (plain) and $(0,56 \%)$ for the Ras Elma Tazekka region (Mountain). This yield is higher than the one quoted by M. Bourkhiss et al. ${ }^{18}$

The results of the chemical analysis of the essential oil of the leaves are grouped in Table 1, according to their Kovats indices ${ }^{19}$. One would expect to lose the more volatile terpenoids during storage, but that does not seem to be the case.

Table 1. The chemical composition of essential oils of T. articulata from two regions studied in Morocco.

\begin{tabular}{|c|c|c|c|c|}
\hline Compounds & Formulas & $\mathbf{K I}$ & Debdou - plain (\%) & $\begin{array}{c}\text { Ras Elma Tazekka - Mountain } \\
(\%)\end{array}$ \\
\hline$\alpha$-Thujone & $\mathrm{C}_{10} \mathrm{H}_{16} \mathrm{O}$ & 931 & 2,51 & 3,12 \\
\hline$\alpha$-Pinene & $\mathrm{C}_{10} \mathrm{H}_{16}$ & 939 & 18,83 & 11,41 \\
\hline Camphene & $\mathrm{C}_{10} \mathrm{H}_{16}$ & 953 & 3,03 & 3,76 \\
\hline$\beta$-Pinene & $\mathrm{C}_{10} \mathrm{H}_{16}$ & 980 & 0,63 & 0,74 \\
\hline$\alpha$-Terpinene & $\mathrm{C}_{10} \mathrm{H}_{16}$ & 1018 & 0,53 & 0,61 \\
\hline p-Cymene & $\mathrm{C}_{10} \mathrm{H}_{14}$ & 1026 & 1,62 & 1,91 \\
\hline Limonene & $\mathrm{C}_{10} \mathrm{H}_{16}$ & 1031 & 8,00 & 10,94 \\
\hline$\alpha$-Campholenal & $\mathrm{C}_{10} \mathrm{H}_{16} \mathrm{O}$ & 1125 & 0,54 & 0,64 \\
\hline cis Limonene oxide & $\mathrm{C}_{10} \mathrm{H}_{16} \mathrm{O}$ & 1134 & 0,51 & 0,53 \\
\hline (E)-Pinocarveol & $\mathrm{C}_{10} \mathrm{H}_{16} \mathrm{O}$ & 1139 & 0,80 & 1,09 \\
\hline Camphor & $\mathrm{C}_{10} \mathrm{H}_{16} \mathrm{O}$ & 1143 & 11,31 & 11,24 \\
\hline Isoborneol & $\mathrm{C}_{10} \mathrm{H}_{18} \mathrm{O}$ & 1156 & 0,48 & 0 \\
\hline Borneol & $\mathrm{C}_{10} \mathrm{H}_{18} \mathrm{O}$ & 1165 & 7,79 & 8,35 \\
\hline 4- Terpineol & $\mathrm{C}_{10} \mathrm{H}_{18} \mathrm{O}$ & 1177 & 0,83 & 1,49 \\
\hline Cymene-8-ol & $\mathrm{C}_{10} \mathrm{H}_{14} \mathrm{O}$ & 1180 & 0,92 & 1,49 \\
\hline$\alpha$-Terpineol & $\mathrm{C}_{10} \mathrm{H}_{18} \mathrm{O}$ & 1189 & 0,52 & 0,62 \\
\hline Myrtenal & $\mathrm{C}_{10} \mathrm{H}_{16} \mathrm{O}$ & 1194 & 0,63 & 0,71 \\
\hline Verbenone & $\mathrm{C}_{10} \mathrm{H}_{14} \mathrm{O}$ & 1204 & 2,27 & 2,49 \\
\hline (E)-Carveol & $\mathrm{C}_{10} \mathrm{H}_{16} \mathrm{O}$ & 1217 & 1,57 & 1,73 \\
\hline (Z)-Carveol & $\mathrm{C}_{10} \mathrm{H}_{16} \mathrm{O}$ & 1229 & 0,47 & 0 \\
\hline Bornyl acetate & $\mathrm{C}_{12} \mathrm{H}_{20} \mathrm{O}_{2}$ & 1285 & 32,55 & 34,84 \\
\hline Carvacrol & $\mathrm{C}_{10} \mathrm{H}_{14} \mathrm{O}$ & 1298 & 0,31 & 0 \\
\hline$\alpha$ - Terpenyl acetate & $\mathrm{C}_{12} \mathrm{H}_{20} \mathrm{O}_{2}$ & 1350 & 0,70 & 1,02 \\
\hline$\alpha$-Copaene & $\mathrm{C}_{15} \mathrm{H}_{24}$ & 1376 & 0,38 & 0 \\
\hline$\gamma$-Elemene & $\mathrm{C}_{15} \mathrm{H}_{24}$ & 1433 & 0,36 & 0 \\
\hline (E)- b-Guaiene & $\mathrm{C}_{15} \mathrm{H}_{24}$ & 1500 & 0,49 & 0 \\
\hline$\gamma$-Cadinene & $\mathrm{C}_{15} \mathrm{H}_{24}$ & 1513 & 0,32 & 0 \\
\hline Diterpene oxide & $\mathrm{C}_{15} \mathrm{H}_{24} \mathrm{O}$ & 1581 & 0,53 & 0,61 \\
\hline Widdrol & $\mathrm{C}_{15} \mathrm{H}_{26} \mathrm{O}$ & 1597 & 0,57 & 0,66 \\
\hline \multicolumn{3}{|c|}{ Total } & 100 & 100 \\
\hline
\end{tabular}


This analysis identified 29 compounds in our essential oil of the region of Debdou (Plain), representing $100 \%$ of the total composition, and 22

The chemical composition of the essential oils of the two regions is more or less similar, with some degrees of difference. Also, the essential oil of the region of Debdou (Plain) contains 22 compounds identical to those of Ras Elma Tazakka (Mountain). There is a difference especially for percentages of major components respectively between Ras Elma Tazekka and Debdou : Bornyl acetate : $(34,84 \%$; $32,55 \%), \alpha$-Pinene $\quad(11,41 \% ; 18,83 \%)$,Camphor $(11,24 \% 11,31 \%)$, Limonene $(11,94 \% ; 8 \%)$ and compounds in that of Ras Elma Tazakka (Mountain), representing $100 \%$ of the total composition.

Borneol $(8,35 \% ; 7,79 \%)$. Also, we notice the absence of some compounds in Ras Elma Tazekka region as Sesquiterpene hydrocarbons (Table 2).

The global and detailed study of the chemical composition of essential oil of both regions prompted us to spread the compounds identified in terpenes hydrocarbons and terpenes oxygenated (ketones, alcohols, esters, aldehydes, and others ...; Table 2).

Table 2. Distribution according: Monoterpene hydrocarbons of T. articulata in class in two areas.

\begin{tabular}{|c|c|}
\hline Debdou-plain (\%) & Ras Elma Tazekka-moutnain (\%) \\
\hline \multicolumn{2}{|c|}{ Ketones } \\
\hline 16,09 & 16,85 \\
\hline \multicolumn{2}{|c|}{ Monoterpenic hydrocarbons } \\
\hline 32,64 & 29,37 \\
\hline \multicolumn{2}{|c|}{ Mono and diterpene } \\
\hline 1,04 & 1,14 \\
\hline \multicolumn{2}{|c|}{ Aldehyde } \\
\hline 1,17 & 1,35 \\
\hline \multicolumn{2}{|c|}{ Alcohol } \\
\hline 14,26 & 15,43 \\
\hline \multicolumn{2}{|c|}{ Ester } \\
\hline 33,25 & 35,86 \\
\hline \multicolumn{2}{|c|}{ Sesquiterpene hydrocarbons } \\
\hline $\mathbf{1 , 5 5}$ & 0,00 \\
\hline
\end{tabular}

The essential oil of the region of Debdou (Plain) contains monoterpenic hydrocarbons with a percentage of $32.64 \%$. Also, the esters represent the highest rate of $33.25 \%$, followed by ketones with a percentage of $16.09 \%$ and alcohols $(14.26 \%)$.

The essential oil of the Ras Elma Tazakka (Mountain) region is rich in esters $(35.68 \%)$, ketones $(16.85 \%)$ and alcohols (15.43\%), Monoterpenic hydrocarbons account for $29.37 \%$.

The results of the chemical composition of the essential oils extracted from the leaves of $T$. articulata from the two regions studied thus show qualitative homogeneity and stability, except a few compounds present in some samples and absent in others.

The comparative studies carried out on the essential oil of $T$. articulata of the different provenances of Morocco thus reveal the heterogeneity of the majority composites. Barrero and al. (2005) thus characterized the essential oils of leaves of $T$. articulata from the region of Tetouan (Morocco) by the predominance of camphor $(19.10 \%)$, bornyl acetate $(16.50 \%)$ and terminalol (9.60\%); Satrani (2006), cited 2,5 dimethoxyacetophenone $(22.5 \%), \quad \beta$-acorenol $(20.4 \%)$ and cedrol $(12.2 \%)$ as major compounds; Bourkhiss et al. (2007), who studied the essential oils of T. articulata leaves from the Khmisset region (Morocco), reported bornyl acetate (30.74\%), $\alpha$-pinene $(23.54 \%)$, camphor $(17.27 \%)$ and limonene $(23.31 \%)$.

The Majority compounds vary quantitatively and qualitatively as a result of ecological conditions, the geographical origin, the analysis part of the species (Bourkhiss and al., 2007), of the mode of extraction and under the effect of interspecific hybridization ${ }^{20}$.

\section{Antimicrobial tests}

The results of the antibacterial activity of the essential oil of $T$. articulata leaves (Vahl) are given in Table 3. 
Table 3. Antibacterial activity in the essential oil of T. articulata leaves (Vahl)

\begin{tabular}{|c|c|c|c|}
\hline \multicolumn{2}{|c|}{} & Debdou (Plain) & $\begin{array}{c}\text { Ras Elma Tazekka } \\
\text { (Mountain) }\end{array}$ \\
\hline \multirow{2}{*}{ Staphylococcus aureus } & $\varnothing$ & $35 \pm 00$ & $20 \pm 00$ \\
\cline { 2 - 4 } & MIC & $6,25 \pm 0,00$ & $6,25 \pm 0,00$ \\
\cline { 2 - 4 } & MBC & $6,25 \pm 0,00$ & $6,25 \pm 0,00$ \\
\hline \multirow{2}{*}{ Escherichia Coli } & $\varnothing$ & $7 \pm 00$ & $8 \pm 00$ \\
\cline { 2 - 4 } & MIC & $50 \pm 0,00$ & $25 \pm 0,00$ \\
\cline { 2 - 4 } & MBC & $50 \pm 0,00$ & $25 \pm 0,00$ \\
\hline \multirow{3}{*}{ Pseudomonas aeruginosa } & $\varnothing$ & $16 \pm 00$ & $14 \pm 00$ \\
\cline { 2 - 4 } & MIC & $6,25 \pm 0,00$ & $6,25 \pm 0,00$ \\
\hline & MBC & $6,25 \pm 0,00$ & $6,25 \pm 0,00$ \\
\hline
\end{tabular}

MBC: Minimal Bactericidal Concentration; MIC: Minimal Concentration of Inhibition; Ø: Zones of Inhibition.

The essential oil of T. articulata (Vahl) has, in vitro, a good inhibitory activity vis-a-vis the tested germs. However, the microorganisms examined did not show the same sensitivity vis-a-vis the essential oil. For bacteria, Staphylococcus aureus showed greater sensitivity for the Debdou region (plain) than the Ras Elma Tazekka region (Mountain) compared to Escherichia coli which is inhibited from the $50 \mu \mathrm{g}$ / $\mathrm{mL}$ concentration for the Debdou region (Plain) and $25 \mu \mathrm{g} / \mathrm{mL}$ for that of the Ras Elma Tazekka region (Mountain). Staphylococcus aureus is gram-positive whereas Escherichia coli and Pseudomonas a gram negative. Gram-negative bacteria are more resistant to essential oils, which is precisely what is happening in our study. Also, the wall of grampositive bacteria is almost exclusively composed of peptidoglycan, which is associated with teichoic acid polymers. The wall of Gram-negative bacteria is more complex.

This observation confirms what has been reported by several works ${ }^{21,22}$. It should be noted also that Pseudomonas aeurginosa presented the same vulnerability to this essence.

The antimicrobial activity of this essential oil is mainly due to its chemical profile. It should be noted that our essence is characterized by the presence of $\alpha$-Pinene (18.83\%) for the plain region known for its inhibitory effect.

This essential oil is characterized by the abundance of l' $\alpha$-Pinene. The bio test performed by Aligiannis et al. (29) on the essential oil of Sideritis sipylea containing as main constituent the $\alpha$-pinene $(35,20 \%)$ has shown that it has high activity against the microorganisms tested.

Noticing also that the essential oil of the leaves T. articulata (Vahl) contains camphor (11.31\%, $11.24 \%)$ and the borneol $(7.79 \%, 8.35 \%)$ respectively for the two regions, constituents known for their antimicrobial activities.
In addition to borneol, the other terpene alcohols (trans-pinocarvenol, 4-terpineol, cymene-8-ol, $\alpha$-terpineol, trans-carveol ...), constituting a $10 \%$ total of this oil, are known by their strong antimicrobial capacity because of their high solubility in water which gives them a high ability to penetrate the walls of bacterial and fungal cells ${ }^{23}$.

On the other hand, esters and especially bornyl acetate $(34.84 \%, 32.55 \%)$, can also participate in the antibacterial and antifungal effect recorded.

However, the synergistic effect between all these chemical constituents can also be taken into account in this activity ${ }^{24,25}$.

\section{Conclusion}

This work is dedicated to the determination of yield, chemical composition, and antibacterial properties the essentials oils isolated from Tetraclinis articulata (Vahl) leaves, which are growing in Tazekka and Debdou (Morocco).

We observe that there is a difference in the yields as well as the percentage of the components of this oil. Which could be explained by an adaptation of the plant to the abiotic factors; such as the climate specific to the regions of origin of the scales, the geographical factors such as the altitude and the nature of the soil; which orient the biosynthesis towards the preferential formation of specific products.

A study on other regions is underway and will be the subject of further publications.

\section{References}

1- N. Achak, A. Romane, M. Alifriqui, R.P. Adams, Chemical studies of leaf essential oils of three species of Juniperus from Tensift Al Haouz-Marrakech Region (Morocco), J. Essent. Oil Res., 2009, 21(4), 337-341. 
2- Y. Abbas, M. Ducousso, M. Abourouh, R. Azon, R. Duponnois, Diversity of arbuscular mycorrhizal fungi in Tetraclinis articulata (Vahl) Masters woodlands in Morocco, Ann. For. Sci. 63 (2006) 285- 291.

3- M. Bourkhiss, M. Ouhssine, M. Hnach, M. Bourkkhis, B. Satrani, A. Farah, Compositon et Bioactivité de l'huile essentielle des rameaux de Tetraclinis Articulata, Bull.Soc.pharm.Bordeau, 2017, 146,75-84.

4- J. Bellakhdar, La pharmacopée Marocaine traditionnelle, The Traditional Moroccan Pharmacopoeia, Ibis Press, Paris 1997.

5- A. P. Mishra, S. Saklani, B. Salehi, V. Parcha, M.Sharifi-Rad, L.Milella, M.Iriti, J. SharifiRad, M. Srivastava, Satyrium nepalense, a high altitude medicinal orchid of Indian Himalayan region: Chemical profile and biological activities of tuber extracts, Cell Mol Bio(Noisy le Grand), 2018, Volume 64 Issue 8.

6- A. P. Mishra, M. Sharifi-Rad, M. A. Shariati, Y. N. Mbkhot, S. S. Al-Showiman, A. Rauf, B. Salhi, M. Zupunski, M. Sharifi-Rad, P. Gusain, J. Sharifi-Rad, H. A. Rasul Suleria, M. Iriti, Bioactive compounds and health benefits of edible Rumex species - a review, Cell Mol Biol (Noisy le Grand), 2018, Volume 64, Issue 8.

7- A. F. Barrero, M. M. Herrador, P. Arteaga, J. Quilez, M. Akssira, F. Mellouki, S. Akkad, Chemical composition of the essential oil of leaves and wood of Tetraclinis articulata (Vahl) Masters, J. Essent. Oil Res., 2005, 17, 166-168.

8- M. Bourkhiss, M. Hnach, B. Bourkhiss, M. Ouhssine, A. Chaouch, Chemical composition and antimicrobial properties of the essential oil extracted from the leaves of Tetraclinis articulata (Vahl) from Morocco, Afrique Sci., 2007, 3, 232-242. French.

9- A. Ziyyat, Z. Legssyer, H. Mekhfi, A. Dassouli, M. Serhrouchni, W. Benjelloun, Phytotherapy of hypertension and diabetes in oriental Morocco, J. Ethnopharmacol., 1997, 58(1), 45-54.

10- M. Bourkhiss, M. Hanach, B. Bourkhiss, M. Ouhssine, M. Chaouch, B. Satrani., Effet de séchage sur la teneur et la composition chimique des huiles essentielles de Tetraclinis articulata (Vahl) Masters, Agro solutions, 2009, 20(1), 44-48.

11- H. W. Woerdenbag, R. M. C. Bos, C. Salomons, H. Hendriks, N. Pras, T. M. Malingre, Volatile constituents of Artemisia annua L (Asteraceae), Flav Fragr J., 1993, 8, 131-137.

12- J. Palá-Paúl, M. J. Pérez-Alonso, A. VelascoNegueruela, P. Ramos-Vázquez, F. Gómez
Contrera, J. Sanz, Essential oil of Santolina rosmarinifolla L ssp. rosmarlnifolia: first isolation of capillene, a dlacetylene derivative. Flavour Fragr. J., 1999, 14, 131-134.

13- A. G. Ponce, R. Fritz, C. Del Valle, S. I. Roura, Antimicrobial activity of essential oils on the native microflora of organic Swiss Chard, LWT-Food Sci, Technol, 2003, 36(7), 679-684.

14- K. Guven, S. Celik, L. Uysal, Antimicrobial activity of Centaurea species Pharmaceutical Biology, 2005, 43, 67-71.

15- G. Iscan, F. Demirci, N. Kirimer, M. Kürkcu“oglu, K. H. C. Baser, Antimicrobial screening: Mentha piperita essential oil, J. Agric. Food. Chem., 2002, 50, 3943-3946.

16- E. W. Koneman, S.D. Allen, W.M. Janda, P.C. Schreckenberger, W. C. Inn, Color atlas and textbook of diagnostic microbiology Philadelphia: Lippincott-Raven Publ., 1997, 785-856.

17- F. Demirci, K. Guven, B. Demirci, M. Y. Dadandi, K. H. C. Baser, Antibacterial activity of two Phlomis essential oils against food pathogens, Food Control, 2008, 19, 1159-1164.

18- M. Bourkhiss, M. Hanach, B. Bourkhiss, M. Ouhssine, M.Chaouch, Composition Chimique et proprieties antimicrobiennes de l'huiles essentielles extraite des feuilles de Tetraclinis articulata (Vahl) du Maroc, Afr. Sci., 2007, 03(02), 232-242.

19- V. I. Babushok, P. J. Linstrom, I. G. Zenkevich, Retention Indices for Frequently Reported Compounds of Plant Essential Oils, J. Phys. Chem. Ref. Data, 2011, Vol. 40, No. 4.

20- D. El Abed, N. Kambouche, Les huiles essentielles. Dar El Gharb, Oran, 2003, pp. 91.

21- F. Hajji, S. Fkih-Tantaoui, A. Tantaoui-Elaraki, Antimicrobial activity of twenty-one Eucalyptus essential oils, Fitoterapia. L XIV, 1993, 1, 71-78.

22- A. Tantaoui-El Araki, N. Lattaoui, A. Errifi, Composition and antimicrobial activity of the essential oil of Thymus broussonetti, J. Essent. Oil. Res., 1993, 5, 45-53.

23- N. Aligiannis, E.Kalpoutzakis, I. B. Chinou, S. Mitakou, E. Gikas, A. Tsarbopoulos, Composition and antimicrobial activity of essential oils of five taxa of Sderitis from Greece, J. Agric. Food Chem., 2001, 49, 811-815.

24- P. Franchomme, L'aromatologie à visée antiinfectieuse, Phytomédecine, 1981, 1(2), 25-47.

25- R. Gueldner, D. M. Wilson, A. Heidi, Volatil compounds inhibiting Aspergillus flavus, J. Agric. Food Chem., 1985, 33, 413-419. 